\title{
Seasonal organic mineralisation and denitrification in intertidal sediments and their relationship to the abundance of Enteromorpha sp. and Ulva sp.
}

\author{
M. Trimmer ${ }^{1, *}$, D. B. Nedwell ${ }^{1}$, D. B. Sivyer ${ }^{2}$, S. J. Malcolm² \\ ${ }^{1}$ Department of Biological Sciences, University of Essex, Colchester CO4 3SQ, United Kingdom \\ ${ }^{2}$ Centre for Environment Fisheries and Aquaculture Sciences, Lowestoft, Suffolk NR33 OHT, United Kingdom
}

\begin{abstract}
Sedimentary organic matter mineralisation (oxygen uptake), nitrogen (N) loss (denitrification) and nutrient exchange were measured seasonally in areas of both high and low Enteromorpha sp. and Ulva sp. cover at 6 sites in 2 harbours on the south coast of England. Measurements of macroalgal and phytoplankton photosynthesis were also carried out. Sedimentary carbon (C) and N cycling was most rapid at the sites with a heavy cover of macroalgae. Macroalgae were responsible, on average, for $57 \%$ of total dark oxygen uptake, with sediment bacterial respiration accounting for the remaining $43 \%$. Dark rates of nutrient uptake for Enteromorpha sp. and Ulva sp. were equivalent to $70 \%$ of those in the light. Denitrification rates were low $\left(D_{\mathrm{w}}\left[\mathrm{NO}_{3}{ }^{-}\right.\right.$from overlying water $]<35$, $D_{\mathrm{n}}$ [coupled to sedimentary nitrification] $<26 \mu \mathrm{mol} \mathrm{N} \mathrm{m} \mathrm{N}^{-2} \mathrm{~h}^{-1}$ ) throughout the harbours, and represented a minor sink for N. Coupled nitrification-denitrification $\left(D_{\mathrm{n}}\right)$ could, on average, account for only 0.3 to $1.7 \%$ of the calculated rate of $\mathrm{N}$ mineralised within the sediment, suggesting that the vast majority of $\mathrm{N}(>98 \%)$ remained within the system. External inputs of nutrients ( $\mathrm{N}$ and $\mathrm{P}$ ) to the harbours may have supported the spring growth of macroalgae, but it seemed unlikely that they were capable of supporting the summer peaks in algal biomass and rapid rates of $\mathrm{N}$ turnover. More likely the intense recycling (ammonification) of organically bound $\mathrm{N}$ within the sediments, coupled to a minimum loss via denitrification, provided a sustained and sufficient $\mathrm{N}$ supply for the macroalgae.
\end{abstract}

KEY WORDS: Enteromorpha $\cdot$ Ulva $\cdot$ Mineralisation $\cdot$ Denitrification $\cdot$ Nutrient exchange

\section{INTRODUCTION}

Nuisance blooms of the rapidly growing macroalgae Enteromorpha sp. and Ulva sp. can have deleterious effects on intertidal communities (Nicholls et al. 1981, Soulsby et al. 1982, Tubbs \& Tubbs 1983, den Hartog 1994). The main effect is a literal blanketing, which can lead to anoxia and sulphide poisoning of the blanketed species (Gamenick et al. 1996). Although some research has established a direct link between nutrient

*Present address: School of Biological Sciences, Queen Mary and Westfield College, University of London, Mile End Road, London E1 4NS, United Kingdom.

E-mail:m.trimmer@qmw.ac.uk loading (e.g. effluent discharge) and the growth of macroalgae (Harlin \& Thorn-Miller 1981, Peckol et al. 1994), evidence to support a causative link between effluent discharge and community structure has remained circumstantial and inconclusive (Soulsby et al 1982, Tubbs \& Tubbs 1983, Lowthion et al. 1985). Heavy growth of macroalgae in the presence of elevated nutrients may in part be due to their position on the littoral zone, shelter from tidal action, light penetration and seasonal temperature (Lowthion et al. 1985 Peckol et al. 1994, Peckol \& Rivers 1996). Because of the attenuation of surface irradiance by blooms of phytoplankton and epiphytic growth, macroalgal abundance has also been shown to decline under high nutrient regimes (Twilley et al. 1985). 
The dominance of the ephemeral macroalgae Enteromorpha sp. and Ulva sp. over other benthic macrophytes may in part be due to their rapid rates of growth under nutrient enrichment (Pedersen \& Borum 1997). The resultant shading from this opportunistic growth of ephemeral macroalgae further suppresses slowgrowing benthic macrophytes. Risgaard-Petersen et al. (1998) reported that the uptake of $\mathrm{NO}_{3}{ }^{-}$and $\mathrm{NH}_{4}{ }^{+}$by Zostera marina was light-dependent, with uptake rates for $\mathrm{NO}_{3}{ }^{-}$being diminished by a factor of 6 in the dark. Enteromorpha sp. and Ulva sp. achieve their peaks in biomass towards the height of summer, when coastal concentrations of dissolved inorganic nitrogen (DIN) are usually low, but because of their low $\mathrm{N}$ storage capacity, these ephemeral macroalgae require a continuously high supply of $\mathrm{N}$ to maintain their dominance (Pedersen \& Borum 1997). This suggests that alternative supplies of $\mathrm{N}$ are available to maintain the summer growth of Enteromorphasp. and Ulva sp. seen in some coastal regions. The role of sedimentary mineralisation as a potential source of $\mathrm{N}$ for Enteromorpha sp. and Ulva sp. is largely unknown.

The aims of the current study were to investigate the importance of sedimentary nutrient recycling to the seasonal abundance of Enteromorpha sp. and Ulva sp. and the effect of light availability on nutrient uptake in areas recognised as suffering from 'nuisance blooms' of these particular macroalgae. In this paper we describe one of the first integrated studies of its kind, combining measurements of sedimentary organic mineralisation, nitrogen loss (denitrification) and nutrient exchange in areas of both high and low macroalgal cover.

\section{MATERIALS AND METHODS}

Sample sites and sediment characteristics. Langstone and Chichester Harbours are tidal inlets on the south coast of England, covering an area of 19 and $36 \mathrm{~km}^{2}$, respectively, of which approx. $3 / 4$ is intertidal. Each of the harbours is connected to the eastern part of the Solent via a narrow channel (Fig. 1). The intertidal areas of both harbours support significant growths of Enteromorpha sp. and Ulva sp. There has been a reported increase (Lowthion et al. 1985) in nutrient loads and areas covered by the algae in Langstone Harbour between the 1950s and the 1970s.

Six sites $(1,2,4,5,7,8)$ were used. Site 1 (Fig. 1) is in an area of relict salt marsh, and was completely covered by Enteromorpha sp. and Ulva sp. (3 to $5 \mathrm{~cm}$ thick at low tide) during the summer. Site 2 is located at the fringes of Site 1, with 40 to $50 \%$ macroalgal cover in the summer. However, sediment sampling was carried out in an area of bare sediment. The area at Site 2 was also visibly colonised by benthic diatoms during the winter and spring. Site 4 had dense but patchy macroalgal cover in the summer, dominated by Enteromorpha sp. with small patches of a filamentous red algae. Macroalgal cover at Site 4 had declined by the autumn, was down to $5-10 \%$ by the winter, and did not return in the spring. Site 7 had no macroalgal cover, but the area was visibly colonised by benthic diatoms during the winter and spring. Sites 5 and 8 were both in Chichester Harbour, with heavy algal cover similar to that at Site 1. Site 5 was at the edge of a Spartina sp. bed, and Site 8 within a relict salt marsh in an enclosed bay.

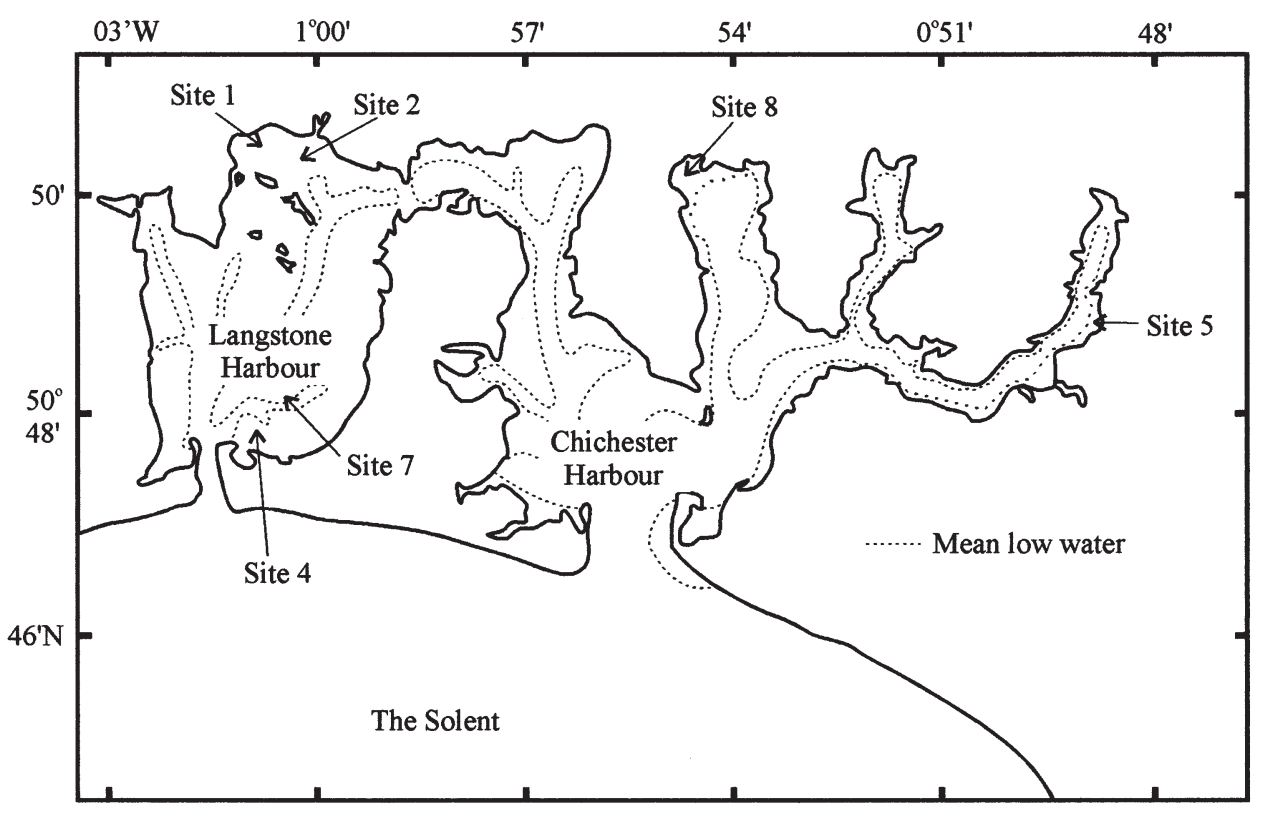

Fig. 1. Sample-site locations in Langstone and Chichester Harbours 
Particle size distribution. Particle size distribution was determined once at each site using single sediment cores $(30 \mathrm{~cm} \times 6 \mathrm{~cm}$ i.d.) to a depth of at least $15 \mathrm{~cm}$. The cores were extruded and sliced at $1 \mathrm{~cm}$ intervals down to $15 \mathrm{~cm}$. Each $1 \mathrm{~cm}$ slice was re-suspended in deionised water using an ultrasonic water bath and wet-sieved through a range of stainless steel meshes (2000, 1000, 500, 250, 125 and $63 \mu \mathrm{m}$ pore sizes), collected, re-dried and each fraction weighed. Each particle size was expressed as a percentage of the total dry weight.

Porosity, sedimentary and macroalgal organic carbon and total nitrogen content. Single sediment cores (as for particle size distribution) were taken at each site on each occasion. Each core was extruded and sliced at $1 \mathrm{~cm}$ intervals down to $10 \mathrm{~cm}$, wet-weighed, freeze dried and re-weighed to determine porosity. Sub-samples of each $1 \mathrm{~cm}$ fraction were then sieved $(500 \mu \mathrm{m})$ to remove large shell fragments and small stones, and ground until they would pass through a $63 \mu \mathrm{m}$ mesh sieve. Preserved samples of macroalgae were rinsed in ultra-high-purity water (UHP) to remove extracellular salt, and oven-dried at $105^{\circ} \mathrm{C}$ to constant weight. Subsamples of both sediment and algae were homogenised with hydrochloric acid (1 $\mathrm{M}$ ) to remove trace carbonate, and after re-drying to a constant weight (Hedges \& Stern 1984) sub-samples (20 mg) were analysed for their organic $\mathrm{C}$ and total $\mathrm{N}$ contents with a CHN analyser (Model 2400, Perkin-Elmer Ltd, Norwalk, CT, USA) calibrated with standard acetanilide (71.09\% C, $10.36 \% \mathrm{~N})$.

Sedimentary sulphide concentrations. Duplicate sediment cores ( 0 to $5 \mathrm{~cm}$ depth) were collected from each of the 6 sites during spring (April 1996) using truncated hypodermic syringes $(20 \mathrm{ml})$, sealed with a Suba-seal and frozen at $-20^{\circ} \mathrm{C}$. The frozen sediment cores were extruded into digestion vessels flushed with oxygen-free nitrogen (OFN) containing $6 \mathrm{~g}$ tin metal and $20 \mathrm{ml}$ degassed UHP water, and the sediment was allowed to defrost. After thawing, the OFM stream flushed any free sulphide (assumed to be $\sum \mathrm{H}_{2} \mathrm{~S}$ $+\mathrm{HS}^{-}+\mathrm{S}^{2-}$ ) into 2 serial zinc acetate traps (each $40 \mathrm{ml}$ of $1 \% \mathrm{w} / \mathrm{v})$. After $30 \mathrm{~min}$ gassing, the traps were replaced and the acid-volatile sulphide (AVS, i.e. FeS iron-monosulphide) and tin-reducible sulphides (TRS, i.e. $\mathrm{FeS}_{2}$ pyrite) were recovered from the sediment by the further addition of stannous chloride solution (30 $\mathrm{ml} 20 \% \mathrm{w} / \mathrm{v}$ in $6 \mathrm{M} \mathrm{HCl}$ ) with heating at $98^{\circ} \mathrm{C}$ for a further $30 \mathrm{~min}$ (Nedwell \& Trimmer 1996). The concentration of sulphide recovered in each fraction was measured using the methylene blue method (American Public Health Association 1976).

Sedimentary concentrations of nitrous oxide. Three sediment cores $(\sim 10 \mathrm{~cm}$ deep) and the overlying water $(\sim 100 \mathrm{ml})$ were collected at low tide (in $\sim 30 \mathrm{~cm}$ deep water) from each site on each occasion using small Perspex core tubes $(20 \mathrm{~cm}$ long $\times 3.4 \mathrm{~cm}$ i.d.) and rubber bungs. Water column and air samples $(20 \mathrm{ml})$ were also collected using serum bottles with butyl stoppers. On return to the laboratory, a slurry of sediment and overlying water was prepared by gentle stirring of the sediment cores. A slurry sample $(20 \mathrm{ml})$ was carefully drawn off into an Exetainer $(12 \mathrm{ml}$ Labco Ltd, High Wycombe, UK) containing $\mathrm{ZnCl}_{2}$ solution (500 $\mu \mathrm{l}, 25 \%$ $\mathrm{w} / \mathrm{v})$ and sealed. After shaking and equilibrating to room temperature, gas samples $(0.2 \mathrm{ml})$ were removed from the headspace of each sample using a gas-tight syringe (Dynatech, Precision Sampling Corporation, Louisiana, USA) and injected into a gas chromatograph (Shimadzu GC 14A, Dyson Instruments, Washington, UK) equipped with a ${ }^{63} \mathrm{Ni}$ electron-capture detector. Gases were separated on a glass column (4 m $\times 2 \mathrm{~mm}$ ) packed with Porapak Q $60-80$ at $25^{\circ} \mathrm{C}$. The detection limit for $\mathrm{N}_{2} \mathrm{O}$ was $55 \mathrm{ppb}$ and was linear up to $10^{7} \mathrm{ppb}$. Peak areas of samples were compared to those of known standards. The in situ air-equilibration concentrations were calculated according to Weiss \& Price (1980).

Temperature. Temperatures were measured with a mercury thermometer inserted into the surface sediment layer.

Water-column nutrients and salinity. Site water (40 1) was collected from each site just prior to tidal exposure at low tide using plastic containers $(4 \times 101)$. Sub-samples $(10 \mathrm{ml})$ were filtered $(0.2 \mu \mathrm{m}$, Minisart Plus $^{\mathrm{TM}}$, Sartorius UK Ltd), preserved with mercuric chloride solution (100 $\mu \mathrm{l}, 0.2 \% \mathrm{w} / \mathrm{v}$, Kirkwood 1992) and subsequently analysed for $\mathrm{NO}_{3}{ }^{-}, \mathrm{NO}_{2}{ }^{-}, \mathrm{NH}_{4}{ }^{+}$and $\mathrm{PO}_{4}{ }^{3-}$ using a continuous-flow autoanalyser (Skalar, SA4000, Breda, The Netherlands) according to Kirkwood (1996). Additional sub-samples (200 ml) were collected for salinity determinations and analysed using a salinometer (Autosal, Guildline, USA).

Nutrient exchange across sediment-water interface. Six sediment cores $(\sim 20 \mathrm{~cm}$ deep, with macroalgae if present in situ) and overlying water $(\sim 500 \mathrm{ml})$ were collected from each site at low tide (in $\sim 30 \mathrm{~cm}$ of water) using Perspex tubes $(30 \mathrm{~cm}$ long $\times 10 \mathrm{~cm}$ i.d.) sealed at the bottom with an adjustable piston, and carefully transported back to the laboratory $(<1 \mathrm{~h})$. The sediment height was re-adjusted in the core tube and the overlying water volume was carefully made up to $750 \mathrm{ml}$ with site water; the tube was then capped. Three sediment cores were wrapped in silver foil as dark controls. Tubes containing site water only $\left(\begin{array}{ll}1 & 1\end{array}\right)$, with and without silver foil, were also prepared as water-column controls. The core samples were then incubated at in situ temperature in a water bath under $2(500 \mathrm{~W})$ halogen lamps $\left(\sim 400 \mu \mathrm{mol} \mathrm{m}{ }^{-2} \mathrm{~s}^{-1}\right)$, which is saturating irradiance for both Enteromorpha sp. and 
Ulva sp. (Kirk 1983). After $0.5 \mathrm{~h}$ settling and equilibration with gentle aeration of the overlying water, a midwater sample $(10 \mathrm{ml})$ was withdrawn through the cap using thin tubing and a syringe, filtered, and fixed (as above). Subsequent water samples were taken every $2 \mathrm{~h}$ for $6 \mathrm{~h}$, and a final sample after $24 \mathrm{~h}$.

Oxygen uptake and production. Triplicate sediment cores ( $\sim 20 \mathrm{~cm}$ deep, with algal biomass if present) and overlying water $(\sim 1 \mathrm{l})$ were collected from each of the 6 sites at low tide with Perspex core tubes $(65 \mathrm{~cm}$ long $\times$ $8 \mathrm{~cm}$ i.d.) each sealed at the bottom with a silicon rubber bung. The tubes were capped to reduce movement in the overlying water and to keep perturbation of the surface sediment to a minimum during their transport back to the laboratory $(<1 \mathrm{~h})$. The water column was then gently re-aerated immediately on return to the laboratory and the oxygen saturation was checked with a calibrated dissolved oxygen electrode. Sediment-water oxygen-uptake rates were measured with dissolved oxygen electrodes and data-logging equipment as described by Nedwell \& Trimmer (1996).

Triplicate measurements of oxygen uptake or production were made in the dark and light $(\sim 400 \mu \mathrm{mol}$ $\mathrm{m}^{-2} \mathrm{~s}^{-1}$ ) for the sediment-water, with and without macroalgae present; and for site water alone with and without macroalgae present. Measurements were made in the summer at Sites 4 and 5 for the macroalgae and sediment combined. The experiments were repeated for combined and separate samples of sediment and macroalgae during the autumn and spring, where there was substantial cover of both Enteromorpha sp. and Ulva sp. In the case of the sediment covered with algae, measurements were made with the algae in place and then repeated once the algae had been removed carefully with tweezers. In order to measure oxygen exchange arising solely from the macroalgal mat, triplicate sub-samples of macroalgae were taken and incubated at in situ temperature in site water contained in sealed Perspex chambers $(500 \mathrm{ml})$, and the uptake or production of oxygen was measured in the dark and light $\left(\sim 400 \mu \mathrm{mol} \mathrm{m}{ }^{-2} \mathrm{~s}^{-1}\right)$. The sampled algae was then weighed, dried to a constant dry weight in an oven at $105^{\circ} \mathrm{C}$, and re-weighed. The total biomass of algae in the macroalgal mats on the sediment surface was calculated from the wet weight of sub-samples taken from known areas of sediment.

Denitrification. Denitrification rates were measured using the ${ }^{15} \mathrm{NO}_{3}{ }^{-}$isotope-pairing technique of Nielsen (1992). Nine small sediment cores $(\sim 10 \mathrm{~cm}$ deep) and the overlying water $(\sim 100 \mathrm{ml})$ were collected at low tide (in $\sim 30 \mathrm{~cm}$ of water) using small Perspex core tubes $(20 \mathrm{~cm}$ long $\times 3.4 \mathrm{~cm}$ i.d.) and rubber bungs. At sites with macroalgal cover, cores were taken from small patches of bare sediment. Cores were collected from Sites 1 and 4 during August 1995 and from all 6 sites during November 1995 and January and April 1996. Denitrification was measured at an enrichment of $30 \mu \mathrm{M}^{15} \mathrm{NO}_{3}^{-}$(Rysgaard et al. 1995).

\section{RESULTS}

\section{Sediment characteristics}

\author{
Grain size, porosity, organic C, total N and \\ temperature
}

The top $5 \mathrm{~cm}$ of sediments were dominated by silt and clay particles $(<63 \mu \mathrm{m}$, Wentworth scale of particle distribution; Tait 1981) at Sites 1, 5 and 8, very fine sands $(<125 \mu \mathrm{m})$ at Sites 2 and 7 and fine sands $(<250 \mu \mathrm{m})$ at Site 4 (Table 1). Porosity decreased with depth from 0 to $5 \mathrm{~cm}$ during summer and autumn, but was more uniform during winter and spring (Table 1). There was a clear pattern of increasing atomic C:N ratio of organic matter with depth $(0$ to $5 \mathrm{~cm})$ during summer and spring, but the pattern was less clear at other times of the year (Table 1). There was a significant positive correlation $(\mathrm{p}<0.0001)$ between sediment porosity and sediment organic $\mathrm{C}$ content, suggesting that the muddier sites contained significantly higher amounts of organic $\mathrm{C}$ than the sandier sites. The temperature of the surface sediment peaked at $21^{\circ} \mathrm{C}$ in August and reached a minimum of 2 to $3^{\circ} \mathrm{C}$ in January.

\section{Sedimentary sulphide concentrations}

The total reduced inorganic sulphur (TRIS) pool (Table 2) ranged from $69 \mu \mathrm{mol} \mathrm{S} \mathrm{cm}{ }^{-3}$ at Site 7 to $214 \mu \mathrm{mol} \mathrm{S} \mathrm{cm}{ }^{-3}$ at Site 8. Free sulphide, on average, made up $<0.2 \%$ of the total TRIS pool. The surfacesediment porosity (Table 1) could be used to calculate the pore-water concentrations of free sulphide, which ranged from $123 \mu \mathrm{M}$ at Site 5 to $385 \mu \mathrm{M}$ at Site 4 (Table 2).

\section{Sedimentary concentrations of nitrous oxide}

Sediment pore-water concentrations of nitrous oxide tended to be lowest in August and April and highest in November and January (Fig. 2). The sedimentary concentrations of $\mathrm{N}_{2} \mathrm{O}$ were significantly correlated with the overlying water-column concentration of $\mathrm{NO}_{3}{ }^{-}(\mathrm{r}=$ $0.8, \mathrm{p}<0.001$ ). Despite the low concentrations of $\mathrm{NO}_{3}{ }^{-}$ in the overlying water column, the pore-water concentrations of $\mathrm{N}_{2} \mathrm{O}$ were as high as those measured in $\mathrm{NO}_{3}^{-}$-enriched estuaries. 
Table 1. Seasonal water-column and sediment characteristics for Langstone (LH) and Chichester (CH) Harbours. T: temperature; S: salinity; TOxN: total oxidised nitrogen, $\mathrm{NO}_{3}{ }^{-}+\mathrm{NO}_{2}^{-}$; nd: not determined

\begin{tabular}{|c|c|c|c|c|c|c|c|c|c|}
\hline \multirow{2}{*}{$\begin{array}{l}\text { Month, } \\
\text { Site }\end{array}$} & \multicolumn{5}{|c|}{ Water column characteristics } & \multicolumn{4}{|c|}{ - Sediment characteristics } \\
\hline & $\begin{array}{c}\mathrm{T} \\
\left({ }^{\circ} \mathrm{C}\right)\end{array}$ & $\begin{array}{c}\mathrm{S} \\
(\% \circ)\end{array}$ & $\begin{array}{l}\text { TOxN } \\
(\mu \mathrm{M})\end{array}$ & $\begin{array}{l}\mathrm{NH}_{4}^{+} \\
(\mu \mathrm{M})\end{array}$ & $\begin{array}{l}\mathrm{PO}_{4}{ }^{3-} \\
(\mu \mathrm{M})\end{array}$ & $\begin{array}{c}\text { Porosity } \\
\left(\mathrm{ml} \mathrm{H}_{2} \mathrm{O} \mathrm{ml} \mathrm{m}^{-1}\right)\end{array}$ & $\begin{array}{l}\text { Organic C } \\
\text { (\% dry wt) }\end{array}$ & $\begin{array}{c}\mathrm{C}: \mathrm{N} \\
\text { (atomic) }\end{array}$ & Particle size \\
\hline \multicolumn{6}{|l|}{ August } & \multicolumn{3}{|c|}{ For $0-1$ and $4-5 \mathrm{~cm}$ depth horizons } & \\
\hline $1 \mathrm{LH}$ & 21 & 33.61 & 2.2 & 2.36 & 2.33 & $0.50-0.46$ & $0.46-0.32$ & $7: 1-19: 1$ & Silt/clay \\
\hline $2 \mathrm{LH}$ & 21 & 34.16 & 1.7 & 2.58 & 1.31 & $0.88-0.60$ & $2.89-1.84$ & $7: 1-15: 1$ & Very fine sand \\
\hline $3 \mathrm{LH}$ & 21 & 34.87 & 1.5 & 0.94 & 0.43 & $0.83-0.73$ & $2.31-1.57$ & $7: 1-11: 1$ & 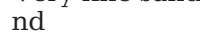 \\
\hline $4 \mathrm{LH}$ & 21 & 35.02 & 1.6 & 2.10 & 0.86 & $0.85-0.54$ & $1.96-0.74$ & $7: 1-12: 1$ & Fine sand \\
\hline $5 \mathrm{CH}$ & 21 & 32.76 & 11.4 & 1.66 & 6.79 & $0.86-0.81$ & $7.78-2.40$ & $6: 1-10: 1$ & Silt/clay \\
\hline $6 \mathrm{CH}$ & 21 & 35.21 & 1.9 & 2.00 & 1.07 & $0.70-0.71$ & $1.94-2.58$ & $8: 1-12: 1$ & nd \\
\hline \multicolumn{10}{|c|}{ November } \\
\hline $1 \mathrm{LH}$ & 11 & 32.78 & 26.8 & 27.90 & 4.58 & $0.58-0.45$ & $0.96-0.59$ & $12: 1-17: 1$ & Silt/clay \\
\hline $2 \mathrm{LH}$ & 10 & 33.74 & 20.6 & 10.00 & 2.57 & $0.77-0.57$ & $1.79-0.87$ & $14: 1-11: 1$ & Very fine sand \\
\hline $4 \mathrm{LH}$ & 11 & 34.75 & 10.2 & 3.01 & 1.13 & $0.64-0.60$ & $0.42-0.77$ & $8: 1-9: 1$ & Fine sand \\
\hline $5 \mathrm{CH}$ & 11 & 31.26 & 76.0 & 9.92 & 8.85 & $0.82-0.75$ & $6.09-2.39$ & $9: 1-10: 1$ & Silt/clay \\
\hline $7 \mathrm{LH}$ & 11 & 34.60 & 12.0 & 2.70 & 0.99 & $0.53-0.48$ & $0.19-0.47$ & $22: 1-18: 1$ & Very fine sand \\
\hline $8 \mathrm{CH}$ & 11 & 34.10 & 16.3 & 2.00 & 2.33 & $0.80-0.68$ & $1.70-1.34$ & $8: 1-8: 1$ & Silt/clay \\
\hline \multicolumn{10}{|l|}{ January } \\
\hline $1 \mathrm{LH}$ & 3 & 32.87 & 33.7 & 18.30 & 2.80 & $0.65-0.49$ & $0.74-0.14$ & $8: 1-3: 1$ & Silt/clay \\
\hline $2 \mathrm{LH}$ & 3 & 32.24 & 50.1 & 22.40 & 3.50 & $0.81-0.63$ & $2.40-1.01$ & $14: 1-9: 1$ & Very fine sand \\
\hline $4 \mathrm{LH}$ & 3 & 33.87 & 23.9 & 8.70 & 1.30 & $0.51-0.53$ & $0.69-0.67$ & $9: 1-10: 1$ & Fine sand \\
\hline $5 \mathrm{CH}$ & 3 & 31.74 & 73.2 & 10.10 & 3.10 & $0.87-0.55$ & $3.24-0.70$ & $8: 1-12: 1$ & Silt/clay \\
\hline $7 \mathrm{LH}$ & 3 & 33.94 & 23.8 & 5.90 & 1.30 & $0.66-0.66$ & $0.44-0.94$ & $9: 1-10: 1$ & Very fine sand \\
\hline $8 \mathrm{CH}$ & 2 & 33.11 & 41.4 & 9.80 & 2.00 & $0.71-0.72$ & $1.11-1.54$ & $6: 1-4: 1$ & Silt/clay \\
\hline \multicolumn{10}{|l|}{ April } \\
\hline $1 \mathrm{LH}$ & 11 & 28.35 & 45.6 & 2.40 & 3.70 & $0.63-0.67$ & $0.91-1.82$ & $12: 1-16: 1$ & Silt/clay \\
\hline $2 \mathrm{LH}$ & 11 & 31.23 & 28.0 & 4.10 & 2.90 & $0.87-0.65$ & $2.05-1.58$ & nd & Very fine sand \\
\hline $4 \mathrm{LH}$ & 10 & 34.10 & 5.5 & 3.30 & 0.80 & $0.51-0.53$ & $0.62-0.85$ & nd & Fine sand \\
\hline $5 \mathrm{CH}$ & 15 & 31.27 & 13.7 & 3.20 & 1.70 & $0.86-0.75$ & $3.03-1.66$ & $10: 1-21: 1$ & Silt/clay \\
\hline $7 \mathrm{LH}$ & 10 & 34.27 & 7.8 & 2.50 & 0.80 & $0.70-0.73$ & $0.91-0.19$ & $8: 1-11: 1$ & Very fine sand \\
\hline $8 \mathrm{CH}$ & 12 & 33.25 & 9.9 & 2.30 & 2.60 & $0.79-0.73$ & $1.90-1.83$ & $14: 1-16: 1$ & Silt/clay \\
\hline
\end{tabular}

\section{In situ water-column salinity, nutrients and temperature}

The harbour waters were virtually fully marine throughout the year, with $>96 \%$ of the salinity samples being $>31 \%$ (Table 1). Lowest salinities (Table 1) were consistently measured at Sites 1, 2 and 5, reflecting the small dilution of the Solent sea water by river and sewage outfalls at these sites, i.e. Budds Farm sewage treatment works (STW) and the Hermitage Stream close to Sites 1 and 2 and Chichester STW at Site 5 (Fig. 1). Concentrations of $\mathrm{NO}_{3}{ }^{-}$and $\mathrm{NH}_{4}{ }^{+}$followed a clear seasonal pattern, both exhibiting winter maxima and summer minima. Nitrate concentrations were significantly negatively correlated with salinity $(\mathrm{p}<$ 0.001 ), suggesting a freshwater or sewage pointsource of $\mathrm{NO}_{3}{ }^{-}$to the harbours. Concentrations of $\mathrm{PO}_{4}{ }^{3-}$ were also significantly negatively correlated with salinity $(p<0.05)$, and remained relatively constant (compared to $\mathrm{NO}_{3}{ }^{-}$and $\mathrm{NH}_{4}{ }^{+}$) throughout the year. Concentrations of $\mathrm{PO}_{4}{ }^{3-}$ were again consistently highest at the northern ends of the harbours, i.e. Sites 1, 2, 5 and 8, suggesting STW origins. The temperature of the harbour waters peaked at $21^{\circ} \mathrm{C}$ in August and reached a minimum of 2 to $3^{\circ} \mathrm{C}$ in January.

\section{Rate measurements}

\section{Nutrient exchange across sediment-water interface}

Overall the sediments (with or without Enteromorpha sp. and Ulva sp. macroalgal cover) were sinks for $\mathrm{NO}_{3}{ }^{-}$and $\mathrm{PO}_{4}{ }^{3-}$ (except in the summer) and sources of $\mathrm{NH}_{4}{ }^{+}$to the overlying water, irrespective of cover or illumination (Fig. 3). ANOVA showed that there was no significant effect of light on the magnitude of either

Table 2. Total reduced inorganic sulphur (TRIS) pool per unit volume wet sediment and concentration of free sulphide in sediment pore-water

\begin{tabular}{|ccc|}
\hline Site & $\begin{array}{c}\text { TRIS } \\
\left(\mu \mathrm{mol} \mathrm{S} \mathrm{cm}{ }^{-3} \text { wet sediment }\right)\end{array}$ & $\begin{array}{c}\text { Free sulphide } \\
\Sigma \mathrm{H}_{2} \mathrm{~S}+\mathrm{HS}^{-}+\mathrm{S}^{2-} \\
(\mu \mathrm{M})\end{array}$ \\
\hline 1 & 206 & 308 \\
2 & 98 & 263 \\
4 & 97 & 385 \\
5 & 200 & 123 \\
7 & 69 & 278 \\
8 & 214 & 132 \\
\hline
\end{tabular}




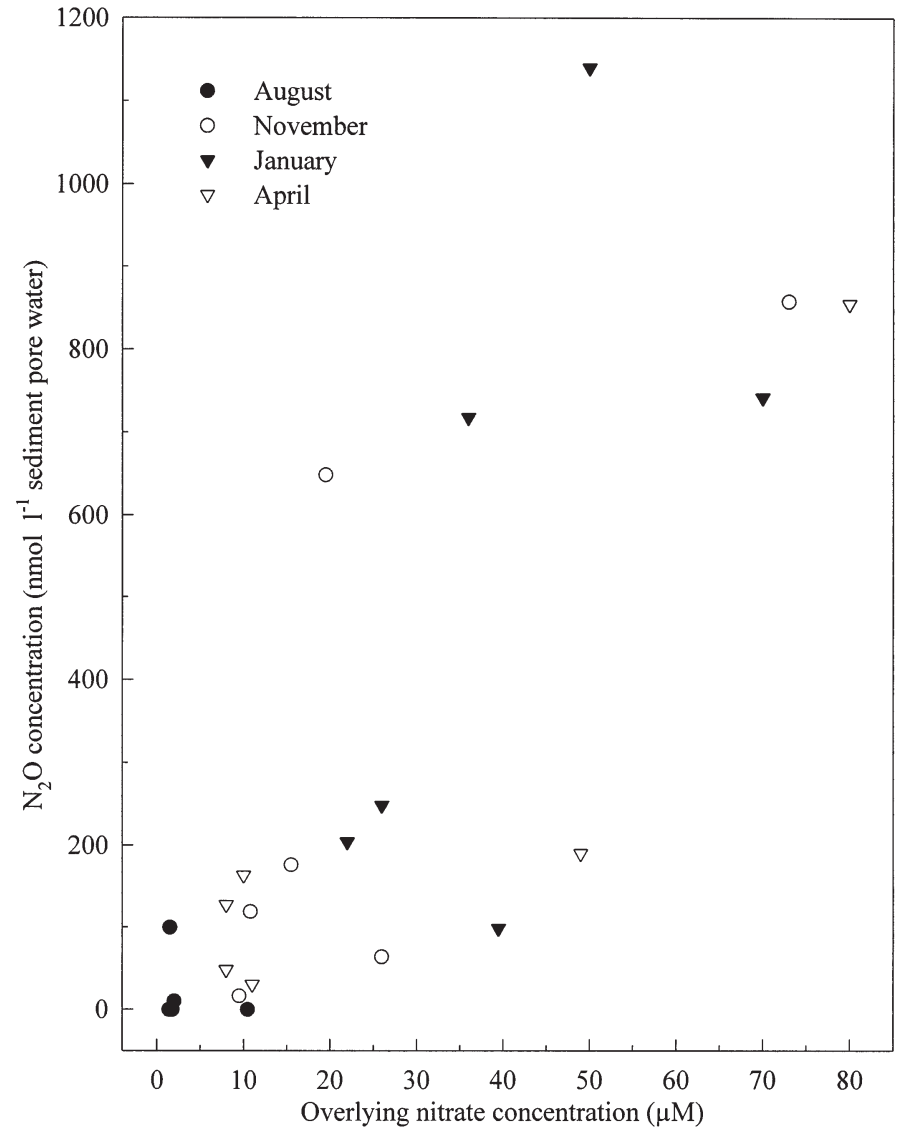

Fig. 2. Scatter plot of harbour-water $\mathrm{NO}_{3}{ }^{-}$concentrations against mean sedimentary $\mathrm{N}_{2} \mathrm{O}$ concentrations throughout year $(\mathrm{r}=0.8, \mathrm{p}<$ $0.001)$

the $\mathrm{NO}_{3}{ }^{-}, \mathrm{PO}_{4}{ }^{3-}$ or $\mathrm{NH}_{4}{ }^{+}$exchange rates, except in January at Site 7 and April at Site 1, when the uptake of $\mathrm{NO}_{3}{ }^{-}$was significantly enhanced in the light $(\mathrm{p}<0.05)$. The relationship between light and dark nutrientexchange rates for sites with macroalgal cover is illustrated in Fig. 4, the dark flux being equivalent, on average, to $70 \%$ of the light flux. The amount of macroalgal biomass in each nutrient-flux chamber was not measured, and therefore the flux rates could not be normalised to biomass. However, the nutrientexchange rates illustrated whether the sediment-algal systems were either sources or sinks for nutrients to the overlying water.

Benthic oxygen uptake

The rate of benthic oxygen uptake was used as a measure of organic mineralisation (Table 3), and the rates measured at the sites with macroalgal cover were significantly higher $(\mathrm{p}<0.05)$ than those measured at the sites without macroalgal cover. In addition, after the macroalgae had been removed, oxygen uptake by uncovered sediment was still significantly higher $(\mathrm{p}<0.05)$ than at the sites with no macroalgal cover. On average, for the entire study, the macroalgae accounted for $57 \%$ of dark oxygen uptake and the sediment $43 \%$. As no algae were present during winter, oxygen uptake was measured for the sediment only (Table 3), and the rates were of the same order of magnitude at each site. On each of the 4 occasions, Site 2 was the only site visited that never had any macroalgal cover and could therefore be used to examine seasonal effects of temperature. There was a strong correlation $(p<0.001)$ between the rate of oxygen uptake and seasonal temperature at this site.

\section{Benthic oxygen production}

In August, illumination of the combined sediment-algae system at Sites 4 and 5 produced an immediate response in oxygen production (Fig. 5 illustrates data for Site 4). Although separate measurements of oxygen production by the benthic macroalgae and the sediment were not made (cf. November and April, Table 3), it was assumed that shading of the sediment surface by the macroalgal mat would have prevented oxygen production by any microphytobenthos. The specific rate of oxygen production by macroalgae in August was $12 \mu \mathrm{mol} \mathrm{O} \mathrm{g}^{-1}$ algae (wet wt) $\mathrm{h}^{-1}$ (SE $\pm 4.5, \mathrm{n}=3$ ), equivalent to $31 \mathrm{mmol} \mathrm{O}_{2} \mathrm{~m}^{-2} \mathrm{~h}^{-1}$ $(\mathrm{SE} \pm 4, \mathrm{n}=3)$; by November it had decreased to $2.4 \mu \mathrm{mol} \mathrm{O} \mathrm{g}^{-1}$ algae (wet wt) $\mathrm{h}^{-1}(\mathrm{SE} \pm 0.6, \mathrm{n}=3)$, equivalent to a mean areal rate of $4.6 \mathrm{mmol} \mathrm{O} \mathrm{m}^{-2} \mathrm{~h}^{-1}$ $(\mathrm{SE} \pm 1.4, \mathrm{n}=3)$. Maximum specific rates of oxygen production were measured in April, i.e. $169 \mu \mathrm{mol} \mathrm{O}_{2}$ $\mathrm{g}^{-1}$ algae (wet wt) $\mathrm{h}^{-1}(\mathrm{SE} \pm 25, \mathrm{n}=9$ ), equivalent to an areal rate of $37 \mathrm{mmol} \mathrm{O}_{2} \mathrm{~m}^{-2} \mathrm{~h}^{-1}(\mathrm{SE} \pm 6, \mathrm{n}=9$ ). Because of the favourable light regime in the macroalgal incubation chambers, the rates of macroalgal oxygen production were a measure of maximum potential rates and not actual in situ rates. However, they provided a useful seasonal comparison. Measurements of primary production in the water column made during the spring showed that pelagic primary production was active in the water column and was, on average for the 6 sites, $51 \mu \mathrm{mol} \mathrm{O}_{2} \mathrm{l}^{-1} \mathrm{~h}^{-1}(\mathrm{SE} \pm 4, \mathrm{n}=18)$.

\section{Denitrification}

The isotope-pairing technique (Nielsen 1992) enables simultaneous measurement of both pathways of denitrification; denitrification driven by nitrate from 

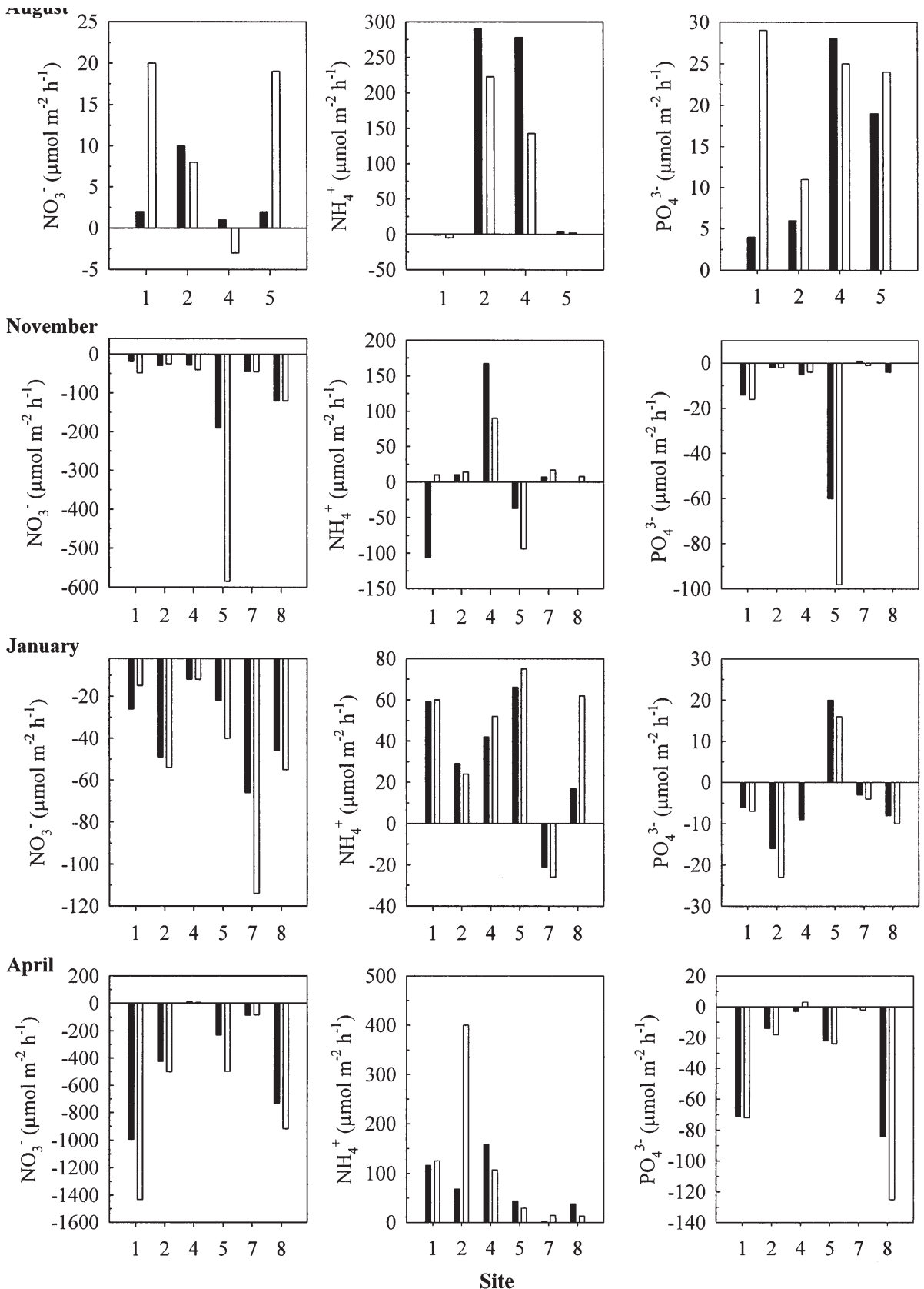

Fig. 3. Rates of sediment-water nutrient exchange for $\mathrm{NO}_{3}{ }^{-}, \mathrm{NH}_{4}{ }^{+}$and $\mathrm{PO}_{4}{ }^{3-}$ at each site. Solid and open bars: sediment cores incubated in dark and light, respectively. Positive values indicate flux from sediment (algae) to water, negative values flux from water to sediment (algae)

the overlying water $\left(D_{\mathrm{w}}\right)$ and that coupled to nitrification of ammonium in the sediment $\left(D_{\mathrm{n}}\right)$. During August, denitrification was dominated by coupled nitrification-denitrification $\left(D_{\mathrm{n}}\right)$ at the 2 sites investigated, i.e. $96 \%$ at Site 1 and $88 \%$ at Site 4 . Rates of uncoupled denitrification $\left(D_{\mathrm{w}}\right)$ were low at both sites (Table 3). Total denitrification $\left(D_{\mathrm{w}}+D_{\mathrm{n}}\right)$ increased in November compared to August, on average from 8 to
$18 \mu \mathrm{mol} \mathrm{N} \mathrm{m}{ }^{-2} \mathrm{~h}^{-1}$. $D_{\mathrm{w}}$ accounted for $56 \%$ of total denitrification, reflecting the higher concentrations of $\mathrm{NO}_{3}{ }^{-}$in the overlying water in November. By January, denitrification was only detectable at Site 4 and was dominated by $\left(D_{\mathrm{w}}\right)$ (Table 3$)$. In April, there were equal rates of $D_{\mathrm{w}}$ and $D_{\mathrm{n}}$ at all sites except Site 1 , where $D_{\mathrm{w}}$ accounted for $100 \%$ of denitrification. This was very similar to the relationship found during autumn 


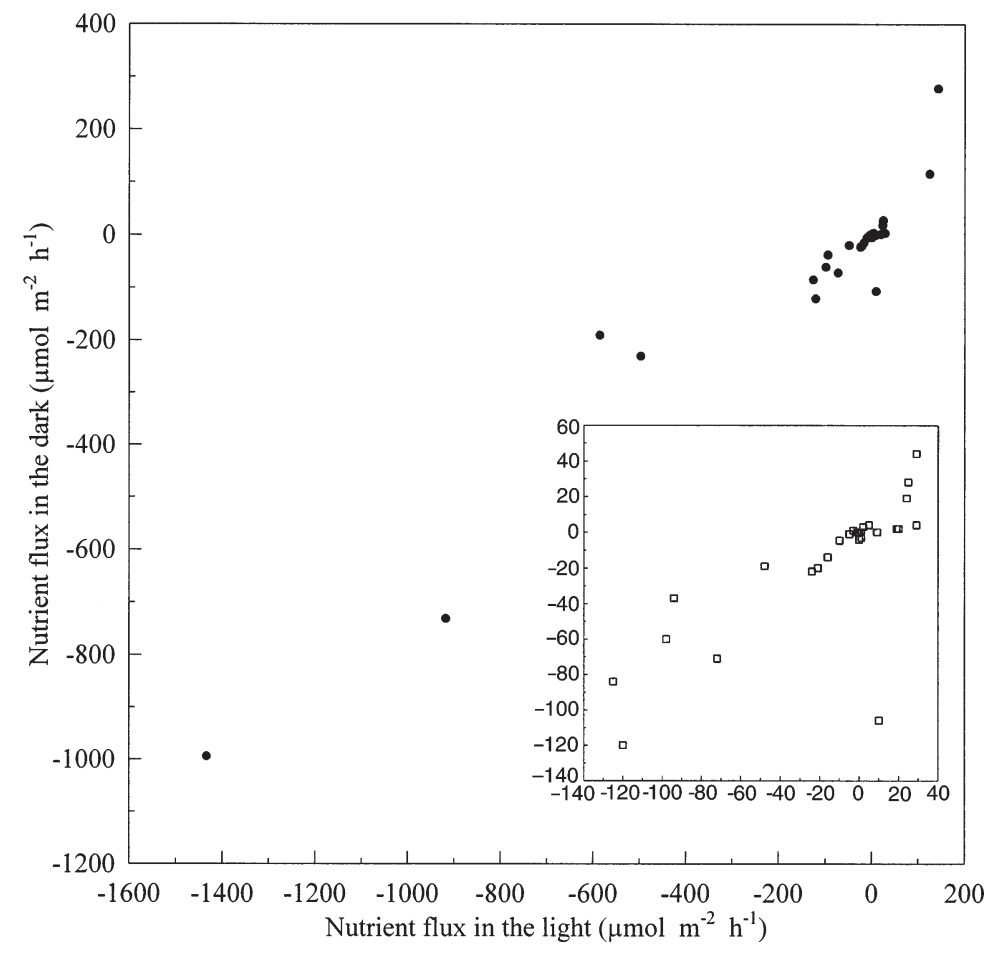

Fig. 4. Scatterplot of dark nutrient-flux measurements $\left(\mathrm{NO}_{3}{ }^{-}, \mathrm{NH}_{4}{ }^{+}, \mathrm{PO}_{4}{ }^{3-}\right)$ vs light nutrient-flux measurements at sites with macroalgal cover. Total data set, slope $V_{Y . X}=0.70$. Calculated using geometric mean Model II regression (Sokal \& Rohlf 1995). Larger fluxes due primarily to uptake of $\mathrm{NO}_{3}{ }^{-}$in spring. Each data point is the mean of triplicate determinations.

Details of smaller fluxes are shown in insert, slope $v_{Y . X}=0.86$
(November), and again contrasted to the very high rates of $D_{\mathrm{n}}$ measured during summer (Table 3). Overall, the rates of $D_{\mathrm{w}}$ were significantly correlated ( $\mathrm{p}<0.05, \mathrm{r}=0.84$ ) with the water-column concentrations of $\mathrm{NO}_{3}{ }^{-}$throughout the harbours.

\section{DISCUSSION}

This study has shown that sedimentary C and $\mathrm{N}$ cycling was significantly elevated $(\mathrm{p}<0.05)$ at sites with a heavy cover of the macroalgae Enteromorpha sp. and Ulva sp. Measurements of solely macroalgal respiration in the autumn and spring (at Sites 1, 5 and 8) suggested that up to $84 \%$ of the gross oxygen demand was attributable to the macroalgae. The high rates of oxygen uptake for sediment with macroalgal mats removed (Table 3) were comparable to those measured by Viaroli et al. (1996) in a similar coastal lagoon subjected to intense growths of $U$. rigida. Even the rates of oxygen uptake measured in the sites with no (Sites 2 and 7) or very low (Site 4) macroalgal cover were in the upper range reported for estuaries (Jørgensen \& Sørensen 1985, Anderson \& Helder 1987, Yoon \& Benner

Table 3. Oxygen-uptake measurements $\pm \mathrm{SE}, \mathrm{n}=3$ and sedimentary rates of denitrification supported by $\mathrm{NO}_{3}{ }^{-}$from overlying water $\left(D_{\mathrm{w}}\right)$ and denitrification coupled to nitrification in sediment $\left(D_{\mathrm{n}}\right)$, data have been rounded to 1 decimal place $\pm \mathrm{SE}, \mathrm{n}=6$. $\mathrm{Alg}+$ Sed: oxygen uptake by sediment and macroalgal mat incubated in dark; Sediment: oxygen uptake by bare sediment and sediment with macroalgae removed; Algae: independent measurements of oxygen uptake by subsamples of macroalgae in dark, converted to areal rates (see 'Materials and methods')

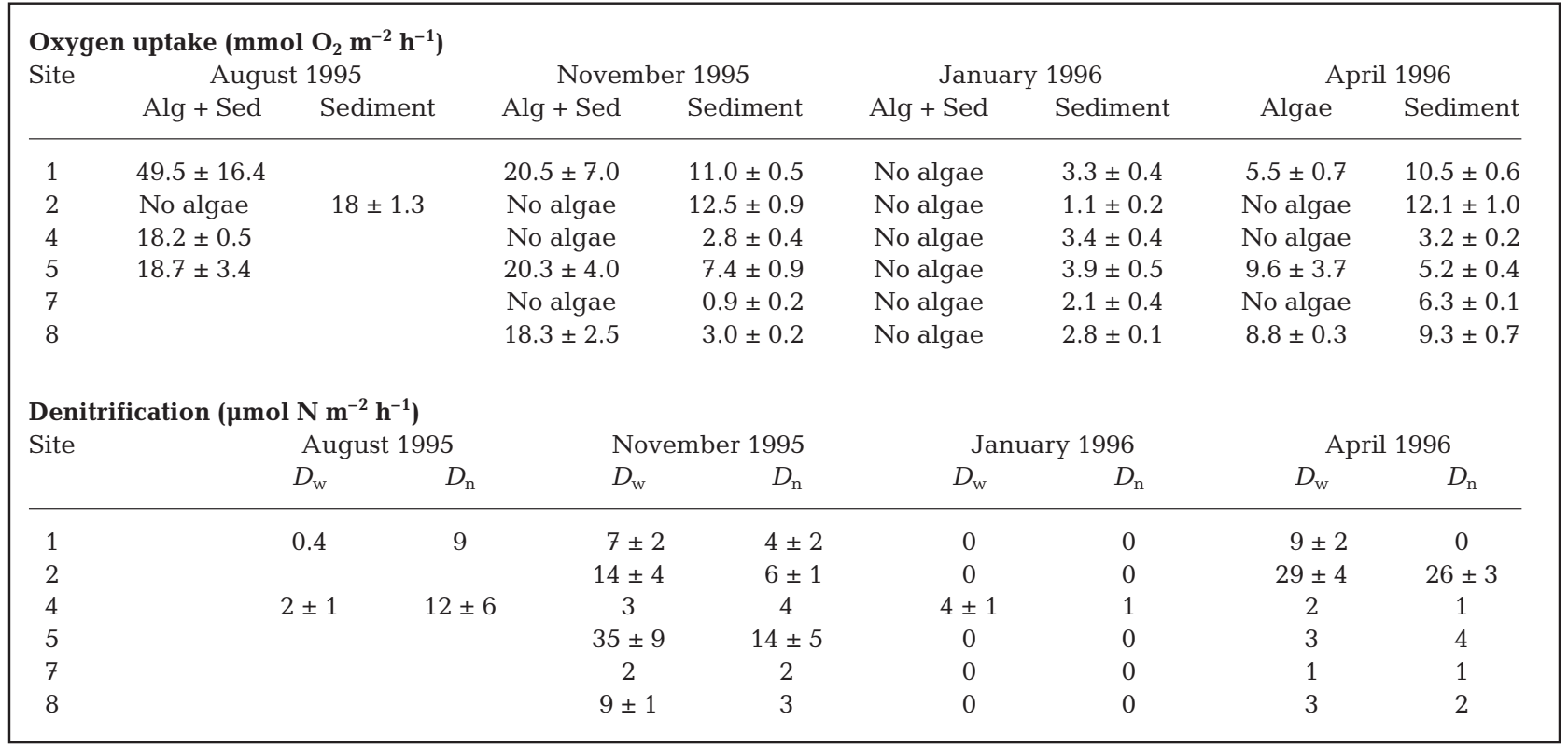




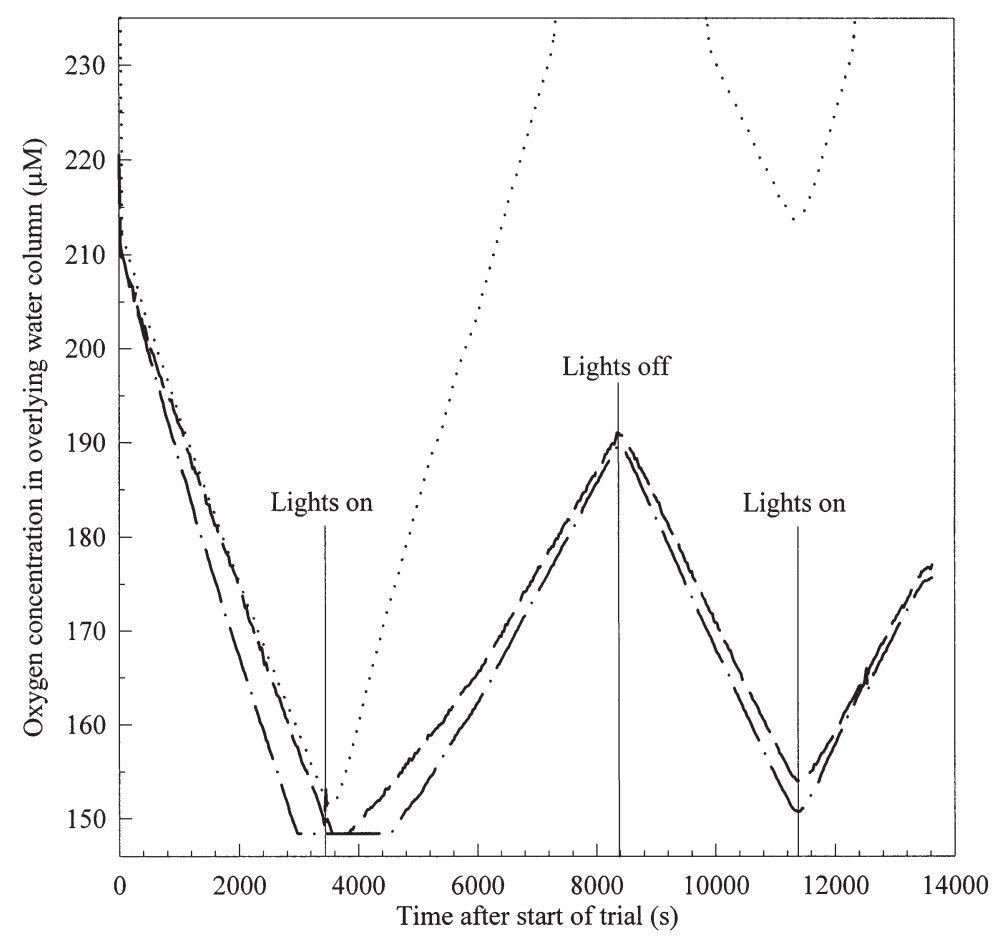

Fig. 5. Change in oxygen concentration in water above sediment with Enteromorpha sp. and Ulva sp. cover, in light and in dark, at Site 4 in August 1995. Different lines represent data from individual cores

1992, Nedwell \& Trimmer 1996), and shallow coastal seas (Hopkinson \& Wetzel 1982, Hansen \& Blackburn 1991, Upton et al. 1993), suggesting that organic matter was advected from areas of high cover to sites with low cover, where it was in turn buried and mineralised (Bach et al. 1986).

High rates of sedimentary oxygen uptake indicated rapid mineralisation of organic matter in the harbour sediments. Owens \& Stewart (1983) calculated that up to $9.52 \mathrm{~g} \mathrm{~N} \mathrm{~m}^{-2} \mathrm{mo}^{-1}$ bound in Enteromorpha sp. biomass were buried during the growing season, equivalent to $9.3 \mathrm{mmol} \mathrm{C} \mathrm{m}^{-2} \mathrm{~h}^{-1}$. A burial rate for $\mathrm{C}$ of this magnitude could account for the measured rates of oxygen uptake for uncovered sediment of 5 to $11 \mathrm{mmol}$ $\mathrm{O}_{2} \mathrm{~m}^{-2} \mathrm{~h}^{-1}$ measured during the spring and autumn at Sites 1, 5 and 8 (Table 3). The top $2 \mathrm{~cm}$ of sediment at the sites with high macroalgal cover were composed of fine sediment and entrapped, very black, partially decayed macroalgae. The average atomic C:N ratio of this surface material was 12:1 during the spring, 7:1 in the summer, and 10:1 in the autumn. This was similar to the C:N range of 6 to $10: 1$ for the macroalgae, indicating that macroalgal biomass was buried and mineralised within the sediment.

The significant correlation $(\mathrm{p}<0.05)$ between $D_{\mathrm{w}}$ and water-column concentrations of $\mathrm{NO}_{3}{ }^{-}$suggested that denitrification $\left(D_{\mathrm{w}}\right)$ was $\mathrm{NO}_{3}{ }^{-}$-limited. Despite the low rates of denitrification, the sediments were supersaturated with $\mathrm{N}_{2} \mathrm{O}$. This was surprising, as these concentrations were similar to those measured in the sediments of estuaries with much higher $\mathrm{NO}_{3}{ }^{-}$(i.e. $>200 \mu \mathrm{M} \mathrm{NO}_{3}{ }^{-}$), such as the Colne and the Great Ouse (Nedwell \& Trimmer 1996, Robinson et al. 1998). The high sedimentary concentrations of $\mathrm{N}_{2} \mathrm{O}$ may have been due to the inhibitory action of the high, sedimentary, free-sulphide concentrations (Table 2) on nitrous oxide reductase (Sørensen et al. 1980) causing denitrification to terminate at $\mathrm{N}_{2} \mathrm{O}$ rather than $\mathrm{N}_{2}$. Maximum concentrations of $\mathrm{N}_{2} \mathrm{O}$ were measured in the winter, when $\mathrm{NO}_{3}{ }^{-}$concentrations were highest, yet denitrification was undetectable except at Site 4 . Termination of the majority of denitrification at $\mathrm{N}_{2} \mathrm{O}$ rather than $\mathrm{N}_{2}$ could lead to an underestimate of denitrification with the isotope-pairing technique.

\section{Sedimentary mineralisation and nitrogen loss}

Overall, the low rates of $D_{\mathrm{w}}$ represented a small sink for $\mathrm{N}\left(\mathrm{NO}_{3}{ }^{-}\right)$in the harbours. To estimate the significance of coupled nitrification-denitrification $\left(D_{\mathrm{n}}\right)$ as a sink for $\mathrm{N}$, we calculated rates of ammonification and compared these to the measured rates of $D_{\mathrm{n}}$. To calculate a stoichiometric $\mathrm{N}$ remineralisation budget (ammonification) for each site with algal cover (Table 4) (according to Nedwell \& Trimmer (1996) and Trimmer et al. (1998)), the measured oxygen-uptake rates for uncovered sediment were used in conjunction with the atomic $\mathrm{C}: \mathrm{N}$ ratio of the surface, sedimentary, organic matter. It was assumed that the measure of oxygen uptake included sulphate reduction because of the aerobic oxidation of sulphide at the sediment surface. Thus, sulphide reoxidation is equivalent to sulphate reduction as each mole of sulphate can oxidise 2 mol of carbon (Jørgensen 1982).

Oxygen respiration with $\mathrm{NH}_{3}$ liberation (Richards et al. 1965) was calculated as:

$$
\left(\mathrm{CH}_{2} \mathrm{O}\right)_{106}\left(\mathrm{NH}_{3}\right)_{16}+106 \mathrm{O}_{2}=106 \mathrm{CO}_{2}+16 \mathrm{NH}_{3}+106 \mathrm{H}_{2} \mathrm{O}
$$

The resulting sulphide was assumed to be completely reoxidised at the expense of oxygen (Schlegel 1975):

$$
\mathrm{H}_{2} \mathrm{~S}+2 \mathrm{O}_{2}=\mathrm{H}_{2} \mathrm{SO}_{4}
$$

Because of the very low rates of denitrification, the organic C flux via denitrification was ignored. It could be argued that oxygen uptake alone does not fully 
Table 4. Stoichiometric sediment N-mineralisation budget for sites with seasonally high coverage of macroalgae

\begin{tabular}{|c|c|c|c|c|c|}
\hline Site (month) & $\begin{array}{c}\text { Sediment } \\
(0 \text { to } 1 \mathrm{~cm}) \\
\text { C:N ratio }(\mathrm{mol})\end{array}$ & $\begin{array}{l}\text { Rate of oxygen uptake } \\
\text { by exposed sediment } \\
\left(\mathrm{mmol} \mathrm{O}_{2} \mathrm{~m}^{-2} \mathrm{~h}^{-1}\right)\end{array}$ & $\begin{array}{c}\text { Mineralised N } \\
(\text { ammonification }) \\
\left(\mu \mathrm{mol} \mathrm{N} \mathrm{m}^{-2} \mathrm{~h}^{-1}\right)\end{array}$ & $\begin{array}{l}\text { Rate of coupled } \\
\text { denitrification }\left(D_{\mathrm{n}}\right) \\
\left(\mu \mathrm{mol} \mathrm{N} \mathrm{m} \mathrm{N}^{-2} \mathrm{~h}^{-1}\right)\end{array}$ & $\begin{array}{l}\% \text { of mineralised } N \\
\text { accounted for by } D_{\mathrm{n}}\end{array}$ \\
\hline 1 (Aug) & 7 & $21.3^{\mathrm{a}}$ & 3180 & 9 & 0.3 \\
\hline 4 (Aug) & 7 & $7.8^{\mathrm{a}}$ & 1060 & 12 & 1.1 \\
\hline 5 (Aug) & 6 & $8.0^{\mathrm{a}}$ & 1380 & 10 & 0.7 \\
\hline 1 (Nov) & 12 & 11.0 & 880 & 4 & 0.5 \\
\hline 5 (Nov) & 9 & 7.4 & 810 & 14 & 1.7 \\
\hline 8 (Nov) & 8 & 3.0 & 360 & 3 & 0.8 \\
\hline 1 (Jan) & 8 & 3.3 & 420 & 0 & 0 \\
\hline 5 (Jan) & 8 & 3.9 & 520 & 0 & 0 \\
\hline 8 (Jan) & 6 & 2.8 & 480 & 0 & 0 \\
\hline 1 (Apr) & 12 & 10.5 & 890 & 0 & 0 \\
\hline 5 (Apr) & 10 & 5.2 & 530 & 4 & 0.8 \\
\hline 8 (Apr) & 14 & 9.3 & 670 & 2 & 0.3 \\
\hline Mean & 9 & 6.6 & 930 & 5 & 0.5 \\
\hline
\end{tabular}

integrate sediment mineralisation rates (Middelburg et al. 1995), especially if free sulphide is escaping from the sediment surface. Viaroli et al. (1996) did measure an immediate and substantial flux of free sulphide from sediment covered with Ulva rigida, but did not record a flux of free sulphide from bare sediment until after $>12 \mathrm{~h}$ incubation. As the incubation times used here were usually $<2 \mathrm{~h}$, we believe that measurements of oxygen uptake do provide a reliable measure of sediment mineralisation rates, as argued by Nedwell \& Trimmer (1996) and Trimmer et al. (1998). Middelburg et al. (1996) measured organic C mineralisation by integrating $\mathrm{CO}_{2}$ and $\mathrm{CH}_{4}$ fluxes from intertidal estuarine sediments, and their reported range of annual $\mathrm{C}$ flux values for the mid- to high-salinity region of the Westerschelde (8 to $28 \mathrm{~mol} \mathrm{C} \mathrm{m}{ }^{-2} \mathrm{yr}^{-1}$ ) compared well with our own C-flux estimates in the Great Ouse (calculated from the measured rates of oxygen uptake and denitrification) of 25 to $37 \mathrm{~mol} \mathrm{C} \mathrm{m} \mathrm{yr}^{-1}$ (Trimmer et al. 1998).

Coupled denitrification $\left(D_{\mathrm{n}}\right)$ could only account for a very small proportion (Table 4 ) of remineralised $\mathrm{N}$ ( 0.3 to $1.7 \%)$, which suggested that the vast majority (>98\%) of $\mathrm{N}$ remineralised within the sediment remained as $\mathrm{NH}_{4}{ }^{+}$or as microbial biomass (Pedersen et al. 1999). Rysgaard et al. (1996), in a coastal lagoon similar to the areas used in the current study, concluded that only a minor fraction $(\leq 8 \%)$ of ammonified $\mathrm{N}$ was lost via coupled nitrification-denitrification, and Risgaard-Petersen et al. (1998) reported similar low rates of $\mathrm{N}$ removal in a Zostera marina meadow. This degree of uncoupling of ammonification from denitrification was in stark contrast to that reported in the sediments of the Great Ouse (Nedwell \& Trimmer 1996, Trimmer et al. 1998) and other estuaries and coastal seas (Billen 1978, Seitzinger et al. 1980, Ogilvie et al. 1997). Sloth et al. (1995) argued that nitrification may be depleted in organically enriched sediments by the death of nitrifying bacteria caused by high levels of free sulphide (Henriksen \& Kemp 1988). Besides nitrification being inhibited by either a reduced oxic layer or free sulphide, the ratio of $\mathrm{C}: \mathrm{NO}_{3}{ }^{-}$could explain reduced rates of denitrification in organically enriched sediments. King \& Nedwell (1985) argued that as the ratio of $\mathrm{C}: \mathrm{NO}_{3}{ }^{-}$increases (i.e. in low $\mathrm{NO}_{3}{ }^{-}$-high $\mathrm{C}$ marine environments), electron disposal is maximised by the complete reduction of $\mathrm{NO}_{3}{ }^{-}$to $\mathrm{NH}_{4}{ }^{+}\left(\mathrm{NO}_{3}{ }^{-}\right.$ ammonification) rather than by a partial reduction to $\mathrm{N}_{2}$ (denitrification).

\section{Macroalgal nitrogen budget}

Macroalgal biomass and percentage cover of macroalgae in both Langstone and Chichester Harbours between 1978 to 1982 have been extensively described (Lowthion et al. 1985). We have used this data set to calculate the macroalgal $\mathrm{N}$ budget. Lowthion et al. (1985) showed a clear seasonal pattern to the percentage of macroalgal cover, with a peak in July to August and minimum cover throughout winter and early spring. The average peak biomass for macroalgae ranged from $31.9 \mathrm{~m}^{-2}$ to $49.4 \mathrm{~g}$ (dry wt) $\mathrm{m}^{-2}$ during 1978 to 1982 (Table 5), with an overall 5 yr mean of $38 \mathrm{~g}$ (dry wt) $\mathrm{m}^{-2}$ (Lowthion et al. 1985). Data covering 1994 to 1996 were only collected in August (Table 5; UK Environment Agency unpubl. data). On average, peak biomass and standing crop increased from 38 to $67 \mathrm{~g}$ (dry wt) $\mathrm{m}^{-2}$ and from 5170 to $8627 \mathrm{t}$, respectively, during the 2 periods. 
Table 5. Peak macroalgal biomass (August) in Langstone Harbour for 8 yr from 1978 to 1996 (see 'Discussion: Macroalgal nitrogen budget' for data sources)

\begin{tabular}{|ccc|}
\hline Year & $\begin{array}{c}\text { Annual peak algal biomass } \\
\left(\mathrm{g} \mathrm{m}^{-2} \text { dry wt) }\right.\end{array}$ & $\begin{array}{c}\text { Standing crop } \\
(\mathrm{t} \text { fresh wt) }\end{array}$ \\
\hline 1978 & 49.4 & 6121 \\
1979 & 36.1 & 5057 \\
1980 & 41.4 & 5895 \\
1981 & 33.9 & 4479 \\
1982 & 31.9 & 4300 \\
1994 & 72.4 & 7494 \\
1995 & 68.6 & 9223 \\
1996 & 58.8 & 9163 \\
& & \\
\hline
\end{tabular}

Owens \& Stewart (1983) measured growth rates for Enteromorpha sp. over a yearly growth cycle (April to October) and reported specific uptake rates for $\mathrm{NH}_{4}{ }^{+}-\mathrm{N}$ per unit dry weight of Enteromorpha sp. varying from 13-16 $\mathrm{mmol} \mathrm{NH}_{4}{ }^{+}-\mathrm{N} \mathrm{g}^{-1}$ (dry wt) $\mathrm{h}^{-1}$ during the height of the bloom in July and August to $3 \mu \mathrm{mol} \mathrm{NH}_{4}{ }^{+}-\mathrm{N} \mathrm{g}^{-1}$ (dry wt) $\mathrm{h}^{-1}$ during the decline in biomass in October. Although we assumed an equal rate of $\mathrm{N}$ assimilation for both Enteromorpha sp. and Ulva sp., higher summer $V_{\max }$ values of 20 and $72 \mu \mathrm{mol} \mathrm{N} \mathrm{g}^{-1}$ (dry wt) $\mathrm{h}^{-1}$ (for $\mathrm{NO}_{3}{ }^{-}$and $\mathrm{NH}_{4}{ }^{+}$, respectively) for Ulva lactuca have been reported (Pedersen \& Borum 1997). The seasonal $\mathrm{NH}_{4}{ }^{+}$uptake rates of Owens \& Stewart were

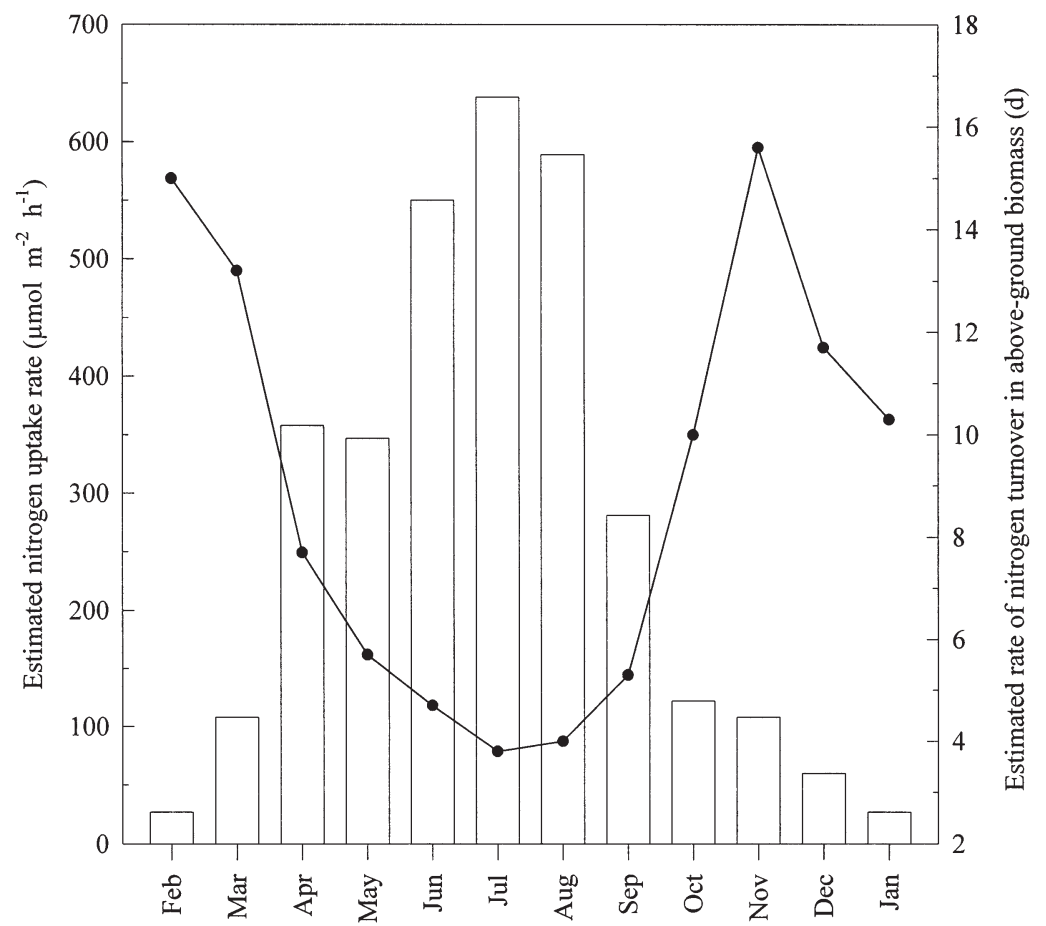

Fig. 6. Calculated seasonal macroalgal $\mathrm{N}$ demands; areal rate of uptake (bars) and consequent rate of $\mathrm{N}$ turnover in above-ground macroalgal biomass ( used in conjunction with the biomass measurements of Lowthion et al. (1985) to calculate a $\mathrm{N}$ demand per unit area of macroalgae throughout the year (Fig. 6). The stoichiometric $\mathrm{N}$-mineralisation rates were then compared to the modelled seasonal $\mathrm{N}$-uptake rates and the measured rates of nutrient exchange. The $\mathrm{N}$ turnover time (d) within the macroalgal biomass was calculated by dividing the $\mathrm{N}$ biomass by the integrated rate of $\mathrm{N}$ assimilation. Because there were still substantial quantities of Enteromorpha sp. and Ulva sp. present at Sites 1, 5 and 8 in November, the minimum specific N-uptake rate from Owens \& Stewart (1983) was used to extend the data set throughout the year.

At the start of the year, the percentage cover by the dominant Enteromorpha sp. and Ulva sp. was between 10 to $12 \%$ and would have required between 27 to $32 \mu \mathrm{mol} \mathrm{N} \mathrm{m}^{-2} \mathrm{~h}^{-1}$ (Fig. 6). The turnover time for $\mathrm{N}$ within the macroalgal biomass would have been relatively long, at between 10 and $15 \mathrm{~d}$ (equivalent to 2-3 turnovers of the algal biomass $\mathrm{N}$ in a month). During spring (March to May), the measured macroalgal rate of photosynthesis was at a maximum, i.e. $169 \mu \mathrm{mol} \mathrm{O}_{2}$ $\mathrm{g}^{-1}$ algae (wet wt) $\mathrm{h}^{-1}$, equivalent to an areal rate of $37 \mathrm{mmol} \mathrm{O}_{2} \mathrm{~m}^{-2} \mathrm{~h}^{-1}$. Macroalgal cover increased from 20 to $45 \%$, and modelled $\mathrm{N}$ demand from 108 to $347 \mu \mathrm{mol} \mathrm{N} \mathrm{m}^{-2} \mathrm{~h}^{-1}$. The $\mathrm{N}$ turnover time decreased markedly from $13 \mathrm{~d}$ in March to $6 \mathrm{~d}$ in May. Concentrations of $\mathrm{NO}_{3}{ }^{-}$in the overlying water column were still relatively high, and the measured uptake rates for $\mathrm{NO}_{3}{ }^{-}$at Sites 1, 5 and 8 suggested that this demand could have been met from the water column (Fig. 3). However, assuming a $\mathrm{C}: \mathrm{N}$ atomic ratio of 7:1 for phytoplankton (Redfield et al. 1963) and an average spring DIN pool in the water of $21 \mu \mathrm{M}\left(\mathrm{NO}_{3}{ }^{-}+\mathrm{NO}_{2}^{-}+\mathrm{NH}_{4}{ }^{+}\right)$, the average pelagic primary production rate of $53 \mu \mathrm{mol} \mathrm{O} \mathrm{O}^{-1} \mathrm{~h}^{-1}$ would have turned over this $\mathrm{N}$ pool in about $2.8 \mathrm{~h}$, or less than half a tidal cycle. It would therefore seem unlikely that benthic macroalgal primary production could be completely supported by the pool of dissolved fixed $\mathrm{N}$ present in the harbour waters. The benthic ammonification of organically bound $\mathrm{N}$ at the sites with high macroalgal cover (Sites 1, 5 and 8) was on average $700 \mu \mathrm{mol} \mathrm{N} \mathrm{m}^{-2} \mathrm{~h}^{-1}$, which could have provided an additional benthic source of $\mathrm{N}$ directly to the macroalgae. Pedersen et al. (1999) suggested that the majority of $\mathrm{N}$ mineralised under senescent Zostera marina leaves was incorpo- 
rated into microbial biomass, with a resultant low efflux of $\mathrm{NH}_{4}{ }^{+}$from the sediment to the overlying water. Although some of our mineralised $\mathrm{N}$ may have been incorporated into microbial biomass, we cannot say how much; however, the $\mathrm{NH}_{4}{ }^{+}$-efflux data support our hypothesis; similar findings were reported by Sundbäck et al. (1990). The important point is that denitrification represented only a small sink for mineralised $\mathrm{N}$.

Risgaard-Petersen et al. (1998) suggested that the uptake of $\mathrm{NO}_{3}{ }^{-}$and $\mathrm{NH}_{4}{ }^{+}$by Zostera marina leaves was light-dependent, with uptake rates for $\mathrm{NO}_{3}^{-}$being diminished by a factor of 6 in the dark. The dark rates of nutrient uptake for Enteromorpha sp. and Ulva sp. were only diminished by $30 \%$ of those in the light. This ability to sequester nutrients under low-light conditions could provide a competitive edge for these opportunistic algae over other benthic macrophytes, particularly as biomass develops and competition for resources increases.

By summer (June to August), the measured macroalgal rate of photosynthesis had decreased to $12 \mu \mathrm{mol} \mathrm{O}_{2}$ $\mathrm{g}^{-1}$ algae (wet wt) $\mathrm{h}^{-1}$, but percentage cover and $\mathrm{N}$ demand reached their respective maxima of $55 \%$ and $638 \mu \mathrm{mol} \mathrm{N} \mathrm{m} \mathrm{N}^{-2} \mathrm{~h}^{-1}$. The turnover time for $\mathrm{N}$ reached its minimum of $4 \mathrm{~d}$, clearly illustrating the continuous high demand for $\mathrm{N}$ by the ephemeral macroalgae, in contrast to turnover times for $\mathrm{N}$ in Zostera marina of approx. 60 d (Risgaard-Petersen et al. 1998). At this time of peak biomass and highest specific $\mathrm{N}$ demand, water-column concentrations of $\mathrm{NO}_{3}{ }^{-}$and $\mathrm{NH}_{4}{ }^{+}$ reached their lowest seasonal values of 1.4 and $0.9 \mu \mathrm{M}$, respectively. Half-saturation constant, $K_{\mathrm{m}}$, values for Ulva lactuca of $5 \mu \mathrm{M}$ for $\mathrm{NO}_{3}{ }^{-}$and $6 \mu \mathrm{M}$ for $\mathrm{NH}_{4}{ }^{+}$(Pedersen \& Borum 1997) suggest that the macroalgae would be nutrient-limited with respect to the watercolumn concentrations by the height of summer; although Lapointe \& Tenore (1981) suggested that $U$. fasciata could sustain maximum growth at $\mathrm{NO}_{3}{ }^{-}$concentrations of $\sim 1 \mu \mathrm{M}$. The $\mathrm{N}$ demand by the macroalgal mat may therefore have been met by the ammonification of organically bound $\mathrm{N}$ in the underlying sediments. The average calculated rate of ammonification was greatest during the summer $\left(1873 \mu \mathrm{mol} \mathrm{N} \mathrm{m}{ }^{-2}\right.$ $\left.\mathrm{h}^{-1}\right)$, and although higher than the modelled $\mathrm{N}$ requirement (638 $\mu \mathrm{mol} \mathrm{N} \mathrm{m}^{-2} \mathrm{~h}^{-1}$ ), illustrated the potential for mineralisation within the sediments. Further to this, were the peak biomass values for August 1994, 1995 and 1996 used in the model for a maximum summer value, the N demand would increase to 764-941 $\mu \mathrm{mol}$ $\mathrm{N} \mathrm{m}^{-2} \mathrm{~h}^{-1}$. For a $Z$. marina bed, Risgaard-Petersen et al. (1998) suggested a similar shift in nutrient supply from pelagic dominance in April to benthic dominance in August, when concentrations of $\mathrm{NO}_{3}{ }^{-}$and $\mathrm{NH}_{4}{ }^{+}$were diminished in the water column.
By autumn, the measured macroalgal rate of photosynthesis had decreased to a minimal value of $2.4 \mu \mathrm{mol}$ $\mathrm{O}_{2} \mathrm{~g}^{-1}$ algae (wet wt) $\mathrm{h}^{-1}$. Macroalgal cover and $\mathrm{N}$ demand also decreased to $52-40 \%$ and $281-108 \mu \mathrm{mol}$ $\mathrm{N} \mathrm{m}^{-2} \mathrm{~h}^{-1}$, respectively. The combined uptake of $\mathrm{NO}_{3}{ }^{-}$ and $\mathrm{NH}_{4}{ }^{+}$from the water column, measured at Sites 1, 5 and 8 (Fig. 3), could have met this decreased $\mathrm{N}$ demand. The turnover time for $\mathrm{N}$ increased again during the autumn from 5 to $16 \mathrm{~d}$.

In conclusion, external inputs of nutrients to the harbours may have supported the growth of macroalgae at the start of the growing season, but the pelagic phytoplankton $\mathrm{N}$ demand would have subsequently restricted this supply. Nutrient concentrations fell to a seasonal low in the summer and it would seem unlikely that they were capable of supporting the summer peaks in algal biomass and rapid rates of $\mathrm{N}$ turnover of the algal mats. More probably, the intense recycling (ammonification) of organically bound $\mathrm{N}$ within the sediments coupled to a minimum loss via denitrification provided a sustained and sufficient $\mathrm{N}$ supply for the macroalgae.

Acknowledgements. This research was funded under a contract placed by the UK Environment Agency, and its predecessor organisations, with CEFAS to examine nutrient fluxes between algae, water and sediment within Langstone and Chichester Harbours. This work was part of a larger study to establish the eutrophication status of these harbours for the purposes of the Urban Waste Water Treatment Directive. We are particularly grateful for access to laboratory and constant temperature room facilities which were provided at the Agency's Southern Region Laboratories at Waterlooville.

\section{LITERATURE CITED}

American Public Health Association (1976) Standard methods for the examination of water and waste water. APHA, Washington, DC

Anderson FO, Helder W (1987) Comparison of oxygen microelectrodes, oxygen flux rate and electron transport system activity in coastal marine sediments. Mar Ecol Prog Ser 37: 259-264

Bach SD, Thayer GW, LaCroix MW (1986) Export of detritus from eelgrass (Zostera marina) beds near Beaufort, North Carolina, USA. Mar Ecol Prog Ser 28:265-278

Billen G (1978) A budget of nitrogen recycling in North Sea sediments off the Belgian coast. Estuar Coast Mar Sci 3: $79-89$

den Hartog C (1994) Suffocation of a littoral Zostera bed by Enteromorpha radiata. Aquat Bot 47:21-28

Gamenick I, Jahn A, Vopel K, Giere O (1996) Hypoxia and sulphide as structuring factors in a macrozoobenthic community on the Baltic Sea shore: colonisation studies and tolerance experiments. Mar Ecol Prog Ser 144:75-85

Hansen LS, Blackburn TH (1991) Aerobic and anaerobic mineralisation of organic material in marine sediment microcosms. Mar Ecol Prog Ser 75:283-291

Harlin MM, Thorne-Miller B (1981) Nutrient enrichment of 
seagrass beds in a Rhode Island coastal lagoon. Mar Biol 65:221-229

Hedges JI, Stern JH (1984) Carbon and nitrogen determinations of carbonate-containing solids. Limnol Oceanogr 29: $657-663$

Henriksen K, Kemp WM (1988) Nitrification in estuarine and coastal marine sediments. In: Blackburn TH, Sørensen J (eds) Nitrogen cycling in coastal marine environments. Wiley, New York, p 207-249 (SCOPE Rep 33)

Hopkinson CS, Wetzel RL (1982) In situ measurements of nutrient and oxygen fluxes in a coastal marine benthic community. Mar Ecol Prog Ser 10:29-35

Jørgensen BB (1982) Mineralisation of organic matter in the sea bed-the role of sulphate reduction. Nature 296: 643-645

Jørgensen BB, Sørensen J (1985) Seasonal cycles of $\mathrm{O}_{2}, \mathrm{NO}_{3}{ }^{-}$ and $\mathrm{SO}_{4}{ }^{2-}$ reduction in estuarine sediments: the significance of an $\mathrm{NO}_{3}{ }^{-}$reduction maximum in spring. Mar Ecol Prog Ser 24:65-74

King DH, Nedwell DB (1985) The influence of nitrate concentration upon the end-products of nitrate dissimilation by bacteria in anaerobic saltmarsh sediment. FEMS Microbiol Ecol 31:23-28

Kirk JTO (1983) Light and photosynthesis in aquatic ecosystems. Cambridge University Press, Cambridge

Kirkwood DS (1992) Stability of solutions of nutrient salts during storage. Mar Chem 38:151-164

Kirkwood DS (1996) Nutrients: practical notes on their determination in seawater. ICES Tech Mar Environ Sci 17

Lapointe BE, Tenore KR (1981) Experimental outdoor studies with Ulva fasciata Delile. I. Interaction of light and nitrogen on nutrient uptake, growth, and biochemical composition. J Exp Mar Biol Ecol 53:135-152

Lowthion D, Soulsby PG, Houston MCM (1985) Investigation of a eutrophic tidal basin: part 1-factors affecting the distribution and biomass of macroalgae. Mar Environ Res 15: 263-284

Middelburg JJ, Klaver G, Nieuwenhuize J, Vlug T (1995) Carbon and nitrogen cycling in intertidal sediments near Doel, Scheldt Estuary. Hydrobiologia 311:57-69

Middelburg JJ, Klaver G, Nieuwenhuize J, Wielemaker A, de Haas W, Vlug T, van der Nat JFWA (1996) Organic mineralisation in intertidal sediments along an estuarine gradient. Mar Ecol Prog Ser 132:157-168

Nedwell DB, Trimmer M (1996) Nitrogen fluxes through the upper estuary of the Great Ouse, England: the role of the bottom sediments. Mar Ecol Prog Ser 142:273-286

Nicholls DJ, Tubbs CR, Haynes FN (1981) The effect of green algal mats on intertidal macrobenthic communities and their predators. Kiel Meeresforsch 5:511-520

Nielsen LP (1992) Denitrification in sediment determined from nitrogen isotope pairing. FEMS Microbiol Ecol 86: $357-362$

Ogilvie B, Nedwell DB, Harrison RM, Robinson A, Sage A (1997) High nitrate, muddy estuaries as nitrogen sinks: the nitrogen budget of the River Colne estuary (United Kingdom). Mar Ecol Prog Ser 150:217-228

Owens NJP, Stewart WDP (1983) Enteromorpha and the cycling of nitrogen in a small estuary. Estuar Coast Shelf Sci 17:287-296

Peckol P, Rivers JS (1996) Contribution by macroalgal mats to primary production of a shallow embayment under high and low nitrogen loading rates. Estuar Coast Shelf Sci 43: 311-325

Peckol P, DeMeo-Anderson B, Rivers J, Valiela I, Maldonado M, Yates J (1994) Growth, nutrient uptake capacities and tissue constituents of the macroalgae Cladophora vaga- bunda and Gracilaria tikvahiae related to site-specific nitrogen loading rates. Mar Biol 121:175-185

Pedersen AGU, Bernsten J, Lomstein BA (1999) The effect of eelgrass decomposition on sediment carbon and nitrogen cycling: a controlled laboratory experiment. Limnol Oceanogr 44:1978-1992

Pedersen MF, Borum J (1997) Nutrient control of estuarine macroalgae: growth strategy and the balance between nitrogen requirements and uptake. Mar Ecol Prog Ser 161: 155-163

Redfield AC, Ketchum BH, Richards FA (1963) The influence of organisms on the composition of seawater. In: Hill MN (ed) The sea, Vol 2. Intersciences, London, p 26-77

Richards FA, Cline JD, Broenkow WW, Atkinson LP (1965) Some consequences of the decomposition of organic matter in Lake Nitinat, an anoxic fjord. Limnol Oceanogr Suppl 10:R185-201

Risgaard-Petersen N, Dalsgaard T, Rysgaard S, Christensen P B, Borum J, McGlathery K, Nielsen LP (1998) Nitrogen balance of a temperate eelgrass Zostera marina bed. Mar Ecol Prog Ser 174:281-291

Robinson AD, Nedwell DB, Harrison RM, Ogilvie BG (1998) Hypernutrified estuaries as sources of $\mathrm{N}_{2} \mathrm{O}$ emission to the atmosphere: the estuary of the River Colne, Essex, UK. Mar Ecol Prog Ser 164:59-71

Rysgaard S, Christensen PB, Nielsen LP (1995) Seasonal variation in nitrification and denitrification in estuarine sediment colonised by benthic microalgae and bioturbating infauna. Mar Ecol Prog Ser 126:111-121

Rysgaard S, Risgaard-Petersen N, Sloth NP (1996) Nitrification, denitrification, and nitrate ammonification in sediments of 2 coastal lagoons in Southern France. Hydrobiologia 329:133-141

Schlegel HG (1975) Mechanisms of chemoautotrophy. In: Kinne O (ed) Marine ecology, Vol 2. John Wiley, London, p 9-60

Seitzinger S, Nixon S, Pilson MEQ, Burke S (1980) Denitrification and $\mathrm{N}_{2} \mathrm{O}$ production in near-shore marine sediments. Geochim Cosmochim Acta 44:1853-1860

Sloth NP, Blackburn H, Hansen LS, Risgaard-Petersen N, Lomstein BA (1995) Nitrogen cycling in sediments with different organic loading. Mar Ecol Prog Ser 116:163-170

Sokal RR, Rohlf JF (1995) Biometry. The principles and practice of statistics in biological research, 3rd edn. Freeman \& Co, New York

Sørensen J, Tiedje JM, Firestone RB (1980) Inhibition by sulphide of nitric and nitrous oxide reduction by denitrifying pseudomonas fluorescens. Appl Environ Microbiol 39: 105-108

Soulsby PG, Lowthion D, Houston M (1982) Effects of macroalgal mats on the ecology of intertidal mudflats. Mar Pollut Bull 13:162-166

Sundbäck K, Jönsson B, Nilsson P, Lindström I (1990) Impact of accumulating drifting macroalgae on a shallow-water sediment system: an experimental study. Mar Ecol Prog Ser 58:261-274

Tait RV (1981) Elements of marine ecology, 3rd edn. Butterworths, London

Trimmer M, Nedwell DB, Sivyer D, Malcolm SJ (1998) Nitrogen fluxes through the lower estuary of the Great Ouse, England: the role of the bottom sediments. Mar Ecol Prog Ser 163:109-124

Tubbs CR, Tubbs JM (1983) Macroalgal mats in Langstone Harbour, Hampshire, England. Mar Pollut Bull 14: 148-149

Twilley RR, Kemp MW, Staver KW, Stevenson JC, Boynton WR (1985) Nutrient enrichment of estuarine submersed 
vascular plant communities. 1. Algal growth and effects on production of plants and associated communities. Mar Ecol Prog Ser 23:179-191

Upton AC, Nedwell DB, Parkes RJ, Harvey SM (1993) Seasonal benthic microbial activity in the southern North Sea; oxygen uptake and sulphate reduction. Mar Ecol Prog Ser 101:273-281

Viaroli P, Bartoli M, Bondavalli C, Christian RR (1996) Macro-

Editorial responsibility: Otto Kinne (Editor),

Oldendorf/Luhe, Germany phyte communities and their impact on benthic fluxes of oxygen, sulphide and nutrients in shallow eutrophic environments. Hydrobiologia 329:105-119

Weiss RF, Price BA (1980) Nitrous oxide solubility in water and seawater. Mar Chem 8:347-359

Yoon WB, Benner R (1992) Denitrification and oxygen consumption in sediments of 2 south Texas estuaries. Mar Ecol Prog Ser 90:157-167

Submitted: October 11, 1999; Accepted: March 24, 2000

Proofs received from author(s): August 25, 2000 